\title{
VARIATIONS IN THE PHYSICAL PROPERTIES OF TEAK (Tectona grandis L. F.) PLANTED IN THE BRAZILIAN AMAZON
}

\author{
VARIAÇÕES NAS PROPRIEDADES FÍSICAS DE TECA (Tectona grandis L. F.) PLANTADA NA \\ AMAZÔNIA BRASILEIRA
}

\author{
Marta Feitosa Nunes Rios ${ }^{1}$, Patricia Soares Bilhalva dos Santos ${ }^{1}$, Márcio Rogério da Silva ${ }^{1}$, \\ Sandro Rogério Reis de Carvalho ${ }^{1}$, Alisson Rodrigo Souza Reis ${ }^{1}$
}

${ }^{1}$ Universidade Federal do Pará, Belém, Pará, Brasil-martaederival_rios@hotmail.com, patriciasbs@ufpa.br,marciomrs@ufpa.br,sandrocarvalhoreis@gmail.com\&alissonreis@ufpa.br

\begin{abstract}
Tectona grandis L.f., known as teak, is considered as a promising species for sustainable development in the tropical regions where it has adapted itself. This adaptation is due to its significant plasticity, which combines with biotic and abiotic conditions to alter the properties of the wood. It is therefore, necessary to evaluate the wood in different locations where the species is grown. The objective of this study was to evaluate the performance of the physical properties of the wood as a function of the diametric class and in the longitudinal direction of the trunk, in a plantation in the Brazilian Amazon. To achieve the objective, 20 individual plants were cut down and classified into four diametrical classes. Speciments with dimensions of $2 \times 2 \times 2 \mathrm{~cm} 3$ were removed in a longitudinal direction (base, middle, and top) from the discs taken from the trees. Transverse, tangential, radial, and volumetric wood shrinkage values were obtained, along with anisotropy and density for both the diametrical and longitudinal classes. These variables were subjected to an analysis of variance, the Tukey's test at $5 \%$, and an analysis of the main components. The values in the diameter class classification were $0.37,1.12,1.68,3.04,0.88$, and 0.535 , while in the longitudinal classification of the trunk they were $0.37,1.41,1.84,3.42,1.01$, and 0.526 for the transverse, tangential, radial, and volumetric shrinkage, anisotropy, and density, respectively. The density was higher when the diameter varied from $21.4 \mathrm{~cm}$ to $32.60 \mathrm{~cm}$, and the tangential shrinkage, volumetric shrinkage, and anisotropy were smaller at the base of the trunk, possibly due to the formation of adult wood, which showed a greater stability of the wood.
\end{abstract}

KEYWORDS: Density, Wood quality, Dimensional variation.

RESUMO

A Tectona grandis L. F., conhecida como teca, é considerada como uma espécie promissora para o desenvolvimento sustentável nas regiões tropicais em que se adaptou. Essa adaptação se deve a significativa plasticidade. E essa plasticidade aliada as condições bióticas e abióticas alteram as propriedades da madeira. Com isso, é necessário que se faça a avaliação da madeira nos diferentes locais em que a espécie é cultivada. Diante disso, o objetivo do presente trabalho foi avaliar o desempenho das propriedades físicas da madeira em função da classe diamétrica e no sentido longitudinal do tronco, em um plantio na Amazônia brasileira. Para atingir objetivo, foram derrubas 20 indivíduos, classificadas em quatro classes diamétricas, retirados corpos-de-prova com dimensões de $2 \times 2 \times 2 \mathrm{~cm}$ nos discos do sentido longitudinal (base, meio e topo). Foram obtidas as contrações: transversais, tangenciais, radiais e volumétricas, anisotropia e densidade, tanto nas classes diamétricas, quanto no sentido longitudinal. Essas variáveis foram submetidas a análise de variância, teste de Tukey à 5 \% de significância e análise de componentes principais. Os valores na classificação por classes de diâmetro foram de 0,37, 1,12, 1,68, 3,04, 0,88 e 0,535 e na classificação longitudinal do tronco foram de 0,37, 1,41, 1,84, 3,42, 1,01 e 0,526 para a contração transversal, tangencial, radial e volumétrica, anisotropia e densidade, respectivamente. A densidade é maior quando o diâmetro varia de 21,4 à 32,60 $\mathrm{cm}$ e a contração tangencial, volumétrica e anisotropia são menores na base do tronco, possivelmente, em virtude da formação do lenho adulto, demostrando uma maior estabilidade da madeira.

PALAVRAS-CHAVE: Densidade, Qualidade da madeira, Variação dimensional. 


\section{INTRODUCTION}

Tectona grandis L. F. belongs to the Lamiaceae family, commonly known as "teak." It is a natural species of the Asian rainforests located between $10^{\circ}$ and $25^{\circ} \mathrm{N}$ in the Indian subcontinent and Southwest Asia; found mainly in India, Burma, Thailand, Laos, Cambodia, Vietnam, and Java (TSUKAMOTO FILHO et al., 2003; POLTRONIERI, et al., 2007; LIMA et al., 2011; PELISSARI et al., 2013; COSTA et al., 2015).

Ferreira et al. (2008) reported that teak is a deciduous tree that develops in deep soils, and produces a pest and disease, resistant hardwood with medium density. It has simple, large deciduous leaves, with hair on the axial face. It has large inflorescences and the fruit is double and dry.

Teak is well known in the international timber market due to its economic and social value, and has been considered as a priority species for conservation and management by the International Tropical Timber Organization (ITTO), the International Union of Forest Research Organizations (IUFRO), and the Food and Agriculture Organization of the United Nations (FAO), because of the rampant exploitation and decline of native forests (KOLLERT \& KLEINE, 2017).

Kollert and Kleine (2017) also mentioned that this species is being cultivated in more than 70 tropical countries in Asia, Africa, Latin America, and Australia (est. planting of 4.35 to 6.89 million ha.), due to its desirable characteristics, such as rapid growth, high adaptability, and high economic value.

Brazil has become an important teak producer, being one of the South American countries that have cultivated this species since the early 1960s. The production of this was implemented by the company Cárceres Florestal S.A., in Cárceres, Mato Grosso (RONDON, 2006; IWAKIRI et al., 2014; ROCHA et al., 2015).

According to the Brazilian Tree Industry (IBA), the country had about 7.83 million ha of planted forests in 2018 (93,957 ha which were teak), with planted areas increasing each year (IBA, 2019).

Due to the importance of this species, studies are being developed in several areas, especially the area of chemistry, wherein the species characteristics are analyzed with respect to the chemical components present in the species (QIU et al., 2019; SUAREZ et al., 2019; SURYANTI et al., 2020 and ROSAMAH et al., 2020). Furthermore, ecological and environmental services (PALAKIT et al., 2019; CLÉMENT et al., 2019; PEREZ et al., 2020), biotechnology (AGUILAR et al., 2019), genetics and genetic improvement (SCHUHLI; PALUDZYSZIN FILHO, 2010;
HURTADO et al., 2020;), as well as forest productivity (PELISSARI et al., 2013; SANQUETA et al., 2015; SANTOS et al., 2019; VAIDES-LÓPEZ et al., 2019; and SOUZA et al. 2019) in different locations where this species is planted and commercialized, have been studied.

The studies are mainly focused on wood quality due to the fast growth of these trees, since it has already been shown that the speed of growth has a direct influence on quality; this can be observed when comparing fast growing trees (planted forests) to normal growing trees (native forests) (ANISH et al., 2015; LEMOS et al., 2019). The studies by Lukmandaru and Takahashi, (2008), Motta et al. (2013), Chagas et al. (2014), Queiroz et al. (2016), Oliveira et al. (2019a), Cremonez et al. (2019), Oliveira et al. (2019b), Silva et al. (2019), Batista et al. (2019), GaitanAlvarez et al. (2019), and Berrocal et al. (2020) serve as key examples.

The Brazilian Amazon has historically suffered from the exploitation of its native forests due to the high diversity and quality of the wood of its trees. The constant deforestation and the greater extent of degraded areas encourage the planting of production forests; which have begun less robustly compared to the southern and southeastern regions of Brazil, but has shown to be promising.

The heterogeneity of regional abiotic and biotic factors became fundamental aspects for studies regarding the development and quality of plantations, and the wood of these species. Guimarães et al. (2013) reported the need for more studies to improve species cultivation and production in Brazil, especially regarding the physical properties of wood, which involve density and its variations. These studies have been able to direct us toward the correct use of wood, and although ancient, they remain up to date for the plantation set-up in the Amazon region.

Thus, the objective of this study was to evaluate the physical properties of Tectona grandis wood cultivated in the State of Pará, according to their diameter class and longitudinal measurements of the log.

\section{MATERIALS AND METHODS}

The material studied came from thinning operations in an experimental plantation of Tectona grandis at the Pará experimental station of the Brazilian Agricultural Research Corporation (EMBRAPA), located on the Trans-Amazon Highway at km 40 (Altamira-Itaituba direction), in the municipality of Brasil Novo, western Pará state.

Twenty individuals from a heterogeneous planting 
were selected, planted with a spacing of $3 \mathrm{~m} \times 2 \mathrm{~m}$ and distributed in the following classes, according to Table 1.

Table 1. Number of individuals by diameter class

\begin{tabular}{cccc}
\hline Classes & Class range & $\begin{array}{c}\text { Number of } \\
\text { individuals }\end{array}$ & $\begin{array}{c}\text { Number of testing } \\
\text { specimens }\end{array}$ \\
\hline 1 & $6.60-10.80$ & 5 & 29 \\
2 & $11.20-15.80$ & 5 & 57 \\
3 & $16.20-20.60$ & 5 & 72 \\
4 & $21.40-32.60$ & 5 & 90 \\
\hline
\end{tabular}

Next, three disks were sectioned from the base, middle, and top portions of each individual tree. Later $2 \mathrm{~cm} \times 2 \mathrm{~cm}$ test specimens were collected, containing the region spanning the log pith and bark of each disk. The test specimens were weighed and measured, and then placed in a vacuum pump for saturation, where they remained for one week. They were then removed, weighed, measured again. and placed in a drying chamber at $105^{\circ} \mathrm{C}$ until the weight was constant. They were removed and weighed again for basic density analysis according to NBR 7190/1997.

To assess radial, tangential and volumetric contractions, the methodology of Miranda et al. (2011) and anisotropic factor calculated by the relationship between tangential and radial contractions.

A normality test was performed on the data and a mean comparison test was applied after the analysis of variance, where the Tukey test with $5 \%$ probability and the principal component analysis (PCA) were applied in the assessment of physical properties separately, using the software Past 4.02 .

\section{RESULTS AND DISCUSSION}

The basic wood density ranged from 0.373 to 0.683 $\mathrm{g} / \mathrm{cm}^{3}$ for the diametric classes, with the lowest value observed in class 1 and the highest in class 4 , corresponding to the existing literature (FINGER \& LOGSDON, 2003; MIRANDA et al 2011; LEMOS et al., 2019). It was also observed that class 4 had the highest mean value compared to the other classes and the mean basic density increased, with $0.518 \mathrm{~g} / \mathrm{cm}^{3}$ in class 1 and 0.546 $\mathrm{g} / \mathrm{cm}^{3}$ in class 4 (Table 2 ).

Similarly, Buvaneswaran et al. (2017) discovered that the diameter of a teak tree does not correlate with density of teak wood in southeast Tamil Nadu, India. However, they discovered a correlation in the upstate area. Meanwhile, Berrocal et al. (2020) stated that there is a correlation between the diameter of a teak tree and its density of wood, age, and height while studying plantations in Costa Rica.

Moya et al (2014) states that teaks with diameters ranging from 12 to $30 \mathrm{~cm}$ have substantial quantities of juvenile wood and their heartwood is approximately 6 to $10 \mathrm{~cm}$ in diameter, which corroborates the findings in the first three classes of this study.

The tree diameter and wood density ratio are significantly imprecise and depends on several factors such as age, height, geographical location, environmental conditions, and silvicultural treatments (MOYA et al., 2014; BLANCO-FLÓREZ, 2016). This unstable behavior was also replicated in cellular elements as observed by Souza et al. (2019) while studying the anatomical characteristics of teaks at two locations in the State of Mato Grosso, where the teak fibers and the rays exhibited a different behavior, except for vessel elements. Moreira et al., (2007) also observed radial differences in teak fibers while studying plantations in Espírito Santo and São Paulo in Brazil.

Gaitan-Alvarez et al. (2019), while analyzing teak wood via X-ray densitometry at various locations in Costa Rica, categorized four types of density i.e., uniform growth, stable growth, unstable growth, and false growth depending on growth rings formation.

This demonstrates the variety and plasticity of the wood in these species, reinforcing the theory that they undergo changes to adapt to their environment, but not following a defined pattern; their diameter can correlate with their wood density.

When comparing the average wood densities and height of teaks, the following values were enumerated: $0.501 \mathrm{~g} / \mathrm{cm}^{3}, 0.526 \mathrm{~g} / \mathrm{cm}^{3}$, and $0.551 \mathrm{~g} / \mathrm{cm}^{3}$ at the top, middle, and bottom, respectively (Table 3 ), indicating a decrease in wood density from the teak base upwards. BLANCO-FLÓREZ et al., (2014) also observed a similar behavior in teak plantations in the State of Minas Gerais. However, Miranda et al. (2011), observed the opposite when analyzing timber from unmanaged forests in East Timor. Therefore, proving that several factors influence growth behavior and, consequently, the quality of wood.

The anisotropy in the diameter classes varied from 0.04 to $3.6 \mathrm{~cm}$, where the lowest value was observed in the third class and highest in the fourth, the averages were 0.90, $0.88,0.85$, and 0.90 in the first, second, third, and fourth classes, respectively. There was no statistical difference in the classes, owing to the formation and proportion in juvenile and adult wood. 
Table 2. Mean values of the physical properties of Tectona grandis L. F. for classes.

\begin{tabular}{cccccccc}
\hline Classes & $\begin{array}{c}\text { Transversal } \\
\text { contraction (\%) }\end{array}$ & $\begin{array}{c}\text { Tangential } \\
\text { contraction (\%) }\end{array}$ & $\begin{array}{c}\text { Radial contraction } \\
\mathbf{( \% )}\end{array}$ & $\begin{array}{c}\text { Volumetric } \\
\text { contraction (\%) }\end{array}$ & $\begin{array}{c}\text { Anisotropic } \\
\text { factor }\end{array}$ & $\begin{array}{c}\text { Basic Density } \\
\left(\mathbf{g} / \mathbf{c m}^{\mathbf{3}}\right)\end{array}$ \\
\hline $\mathbf{1}$ & $0,42(0,4) \mathrm{a}$ & $1,10(0,8) \mathrm{a}$ & $1,40(0,8) \mathrm{a}$ & $2,80(1,4) \mathrm{a}$ & $0,90(0,7) \mathrm{a}$ & $0,518(0,06) \mathrm{a}$ \\
$\mathbf{2}$ & $0,35(0,3) \mathrm{a}$ & $1,24(0,8) \mathrm{a}$ & $1,88(1,1) \mathrm{a}$ & $3,32(1,5) \mathrm{a}$ & $0,88(0,6) \mathrm{a}$ & $0,536(0,04) \mathrm{a}$ \\
$\mathbf{3}$ & $0,32(0,3) \mathrm{a}$ & $0,98(0,5) \mathrm{a}$ & $1,73(1,4) \mathrm{a}$ & $2,94(1,5) \mathrm{a}$ & $0,85(0,6) \mathrm{a}$ & $0,542(0,04) \mathrm{a}$ \\
$\mathbf{4}$ & $0,39(0,5) \mathrm{a}$ & $1,19(1,2) \mathrm{a}$ & $1,71(1,3) \mathrm{a}$ & $3,10(2,2) \mathrm{a}$ & $0,90(0,7) \mathrm{a}$ & $0,546(0,05) \mathrm{b}$ \\
\hline
\end{tabular}

For each diameter class, the means followed by the same letter in the columns do not differ from each other by the Tukey test with a $5 \%$ probability of error.

These results were consistent with those of Moya et al. (2014), which reported that the formation of adult wood of diameters from 6 to $10 \mathrm{~cm}$ at approximately 4 to 6 years. However, Gaitan-Alvarez et al. (2019), indicated that adult wood starts forming at 8 years.

When observing lengthwise, mean values of $1.02 \%$, $1.11 \%$, and $0.90 \%$ were observed at the apex, middle, and base, respectively, without any statistical difference. Confirming that teak wood has dimensional stability, considered excellent for several uses. The studies of Damayanti et al. (2007) and Bonduelle et al. (2015) corroborate these findings.

The transversal contraction ranged from 0 to 3.9, the means were $0.42,0.35,0.32$, and 0.39 for the first, second, third, and fourth classes, respectively (Table 2). Lengthwise, the mean values of $0.34,0.44$, and 0.35 were observed at the apex, middle, and base, respectively. It can be observed, therefore, that in this section, the variation is insignificant.

The tangential contraction ranged from 0.10 to 9.8 , both values found in the fourth class, the means were 1.10, $1.24,0.98$, and 1.19 for the first, second, third and fourth classes, respectively (Table 2 ). Lengthwise mean values of $1.99,1.35$, and 0.90 were observed at the apex, middle, and base, respectively. It can be observed, therefore, that there was significant growth in tangential contraction from the base upwards.

Radial contraction ranged from 0.05 to 7.9 , the averages were $1.40,1.88,1.73$, and 1.71 in the first, second, third, and fourth classes, respectively (Table 2). When observing lengthwise, mean values of 1.99, 1.96, and 1.57 were observed at the apex, middle, and base, respectively.

The volumetric contraction ranged from 0.29 to 9.3 , the lowest value was observed in the first diameter class, and the highest in the fourth class, the averages were 2.80, $3.32,2.94$, and 3.10 in the first, second, third and fourth classes, respectively (Table 2 ). When observing lengthwise, the mean values of $4.04,3.43$, and 2.79 were observed at the apex, middle, and base, respectively. This implies that the base had the lowest volumetric contraction.

The values of transversal, radial, tangential and volumetric contractions of this study were significantly lower than those discovered by Miranda et al. (2011) when studying plantations in East Timor. However, they were similar to those discovered by Bonduelle et al. (2015) when studying plantations in the Amazon that highlighted greater dimensional stability of the wood in teaks planted in the Brazilian Amazon. Blanco-Flórez et al. (2014) report that this variable contraction is common when the wood has a significant amount of juvenile xylem

Priya \& Bhat (1999) and Palakit et al. (2019), reported that, compared to dry wood, the growth of teak wood is slower in tropical climates owing to the influence of climate on exchange rate activity. This slow growth influences the dimensional stability of the wood, conferring good quality.

To complement and improve the understanding of the behavior of physical properties both in the diameter class and in the position on the trunk, principal component analysis was applied.

The data were transformed for normalization, and when the parameters analysis (class and longitudinal position) was performed concurrently, the first two axes represented $66 \%$ of the data variation (Figure $1 \mathrm{~A}$ ) and formed three distinct groups: density, transversal contraction and volumetric contraction. However, Rencher (2002) mentions that for a good analysis of the components, they must represent $70 \%$ of the data variation, with this, separate analyzes of the parameters were carried out.

In the analysis only with the diameter classes (Figure 1 B) the first two axes corresponded to $80 \%$ of the data variation and the volumetric contraction is more uniform and tends to be greater in class 4 and the density and the lower and higher transverse contraction in classes 2 and 3, mainly in 3. In these classes (2 and 3), both wood contractions and anisotropy do not present a defined behavior. 
Table 3. Mean values of the physical properties of Tectona grandis L. F. for position.

\begin{tabular}{ccccccc|}
\hline $\begin{array}{c}\text { Position } \\
\text { (stem) }\end{array}$ & $\begin{array}{c}\text { Transversal } \\
\text { contraction (\%) }\end{array}$ & $\begin{array}{c}\text { Tangential } \\
\text { contraction (\%) }\end{array}$ & $\begin{array}{c}\text { Radial } \\
\text { contraction (\%) }\end{array}$ & $\begin{array}{c}\text { Volumetric } \\
\text { contraction (\%) }\end{array}$ & $\begin{array}{c}\text { Anisotropic factor } \\
\text { Basic Density } \\
\left(\mathbf{g} / \mathbf{c m}^{\mathbf{3}}\right)\end{array}$ \\
\hline Top & $0,34(0,5)$ a & $1,99(0,9)$ a & $1,99(0,9)$ a & $4,04(1,1)$ a & $1,02(0,4)$ a & $0,501(0,04)$ a \\
\hline Middle & $0,44(0,6)$ a & $1,35(1,4)$ b & $1,96(1,4)$ a & $3,43(1,5)$ a & $1,11(1,4)$ a & $0,526(0,06)$ a \\
Base & $0,35(0,3)$ a & $0,90(0,5)$ c & $1,57(1,1)$ a & $2,79(1,4)$ b & $0,90(0,9)$ a & $0,551(0,03)$ b \\
\hline
\end{tabular}

For each position of the log, the means followed by the same letter in the columns do not differ from each other by the Tukey test with a $5 \%$ probability of error

As for the analysis in the longitudinal position (Figure 1C) the first two axes correspond to $91 \%$ of the data variation, following behavior similar to those of the diameter class, where the volumetric contraction is less at the base and the greater transverse contraction and density are less evident at the base. In the mid-apex sense, the physical properties did not show a defined pattern.

The formation of three groups was observed, the group of well-defined and distinct density, the group of volumetric and transversal contraction, which are inversely proportional. Although the concomitant analysis of the defined parameters (class and longitudinal position) explains less than $70 \%$ of the data variation, it followed the same pattern for the definition of the groups found.

Tangential and radial contractions and anisotropy are not affected as much in the division by diameter class and along the trunk. This can be explained by being directly related, but they influence when added to other properties such as the case of volumetric contraction and density.

\section{CONCLUSION}

Given the above, variations in teak wood are observed and these variations are intraspecific, highlighting the potential, the characteristics of the wood and how this species behaves in plantations in the Amazon, highlighting the following information:

Teak plantations with diameters from 6 to $32 \mathrm{~cm}$ do not differ or alter the physical properties of the wood, however with increasing diameter the first property to differentiate is the basic density;

Diameters between 6 and $10 \mathrm{~cm}$ have no wood in formation and therefore have no pattern in the behavior of physical properties;

In the longitudinal direction Base-top, the properties of volumetric contraction and density are different, with the base having less contraction and greater density;

Tangential and radial contractions increase in the basetop direction, with a high variation;

The basic density is the property that has less variation both in the diameter class and in the longitudinal direction of the trunk;

Thus, there is a significant plasticity and adaptability of the teak, reinforcing that the environments and management techniques can significantly improve the quality of the wood.

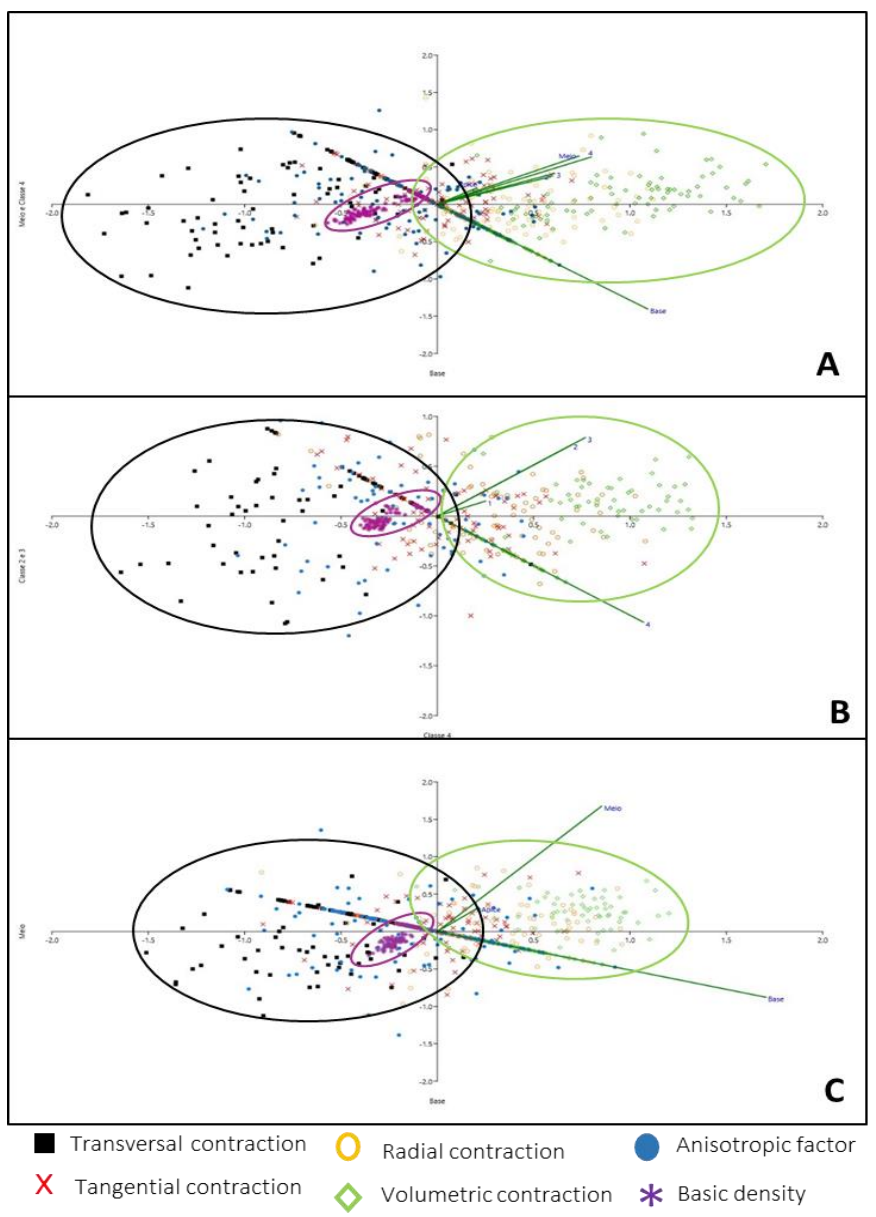

Figure 1. Sorting by principal component analysis (PCA) of the physical properties of Tectona grandis. A relationship of the diameter class and the longitudinal position; B - relationship of the diameter class; C - longitudinal position relationship.

\section{ACKNOWLEDGEMENTS}

The authors thank the National Council for Scientific and Technological Development (CNPq), Pro-Rectory of 
Research, and Graduate Studies, Federal University of Pará (PROPESP /UFPA) and FAPESPA -ICAAF 001/2018 by their financial support.

\section{REFERENCES}

AGUILAR, M.E. et al. Simple Protocol for the micropropagation of teak (Tectona grandis Linn.) in Semi-solid and liquid media in RITA Bioreactors and ex Vitro Rooting. American Journal of Plant Sciences, v.10, n.7, p.1121-1141, 2019.

ANISH, M.C. et al. Effect of growth rate on wood quality of teak (Tectona grandis L. f.): a comparative study of teak grown under differing site quality conditions. Journal of the Indian Academy of Wood Science, v.12, n.1, p.81-88, 2015.

ASSOCIAÇÃO BRASILEIRA DE NORMAS TÉCNICAS - ABNT. NBR 7190:1997 Projeto de estruturas de madeira. Rio de Janeiro: ABNT, 1997.

BERROCAL, A. et al. Development of heartwood, sapwood, bark, pith and specific gravity of teak (Tectona grandis) in fast-growing plantations in Costa Rica. Journal of Forestry Research, v.31, n.2, p.667-676, 2020.

BONDUELLE, G.M. et al. Análise da massa específica e da retratibilidade da madeira de Tectona grandis nos sentidos axial e radial do tronco. Floresta, v.45, n.4, p.671-680, 2015.

BUVANESWARAN, C. et al. Relations between growth traits and wood parameters of Tectona grandis L. F. in even-aged plantations in Tamil Nadu. In: Wood is Good. Singapore: Springer, 2017.

BLANCO-FLÓREZ, J. Comportamento em serviço da madeira jovem de Tectona grandis L. f. com diferentes acabamentos para uso em ambiente externo. 2016. 109p. (Tese de doutorado)

BLANCO-FLÓREZ, J. et al. Characterization of young wood Tectona grandis L. F. planted in Brazil. Madera Bosques, v.20, n.1, p.1120, 2014.

BATISTA, D.C.et al. Moisture of modified wood. BioResources, v.14, n.3, p.5171-5187, 2019.

CLÉMENT, C. et al. Linking tree-rooting profiles to leaf phenology: a first attempt on Tectona grandis Linn F. Trees - Structure and Function, v.33, n.5, p.1491-1504, 2019.

CREMONEZ, V.G. et al. Influence of age on the discrimination of Tectona grandis by VIS/NIR spectroscopy. Floresta e Ambiente, v.26, n.2, p.1-8, 2019.

COSTA, R.B. da et al. Desempenho de progênies no prémelhoramento de Tectona grandis L.f no Estado do Espírito Santo. Scientia Forestalis/Forest Sciences, v.43, n.105, p.211216, 2015.

DAMAYANTI, R. et al. Wood Properties of 5-year-old Fast Grown Teak.Wood Research Journal, v.9, n.2 p.29-34, 2007.

FERREIRA, R.A. et al. Entomofauna observada na cultura da teca (Tectona grandis L. f) no campo. Revista científica eletrônica de
Engenharia Florestal, v.12, p.01-22, 2008.

FINGER, F.A. et al. Qualificação da madeira de teca, Tectona grandis L. F., oriunda do primeiro desbaste comercial, com vistas a seu aproveitamento. MADEIRA: arquitetura e engenharia, v.4, n.10, p.1-31, 2003.

GAITAN-ALVAREZ, J. et al. The use of X-ray densitometry to evaluate the wood density profile of Tectona grandis trees growing in fast-growth plantations. Dendrochronologia, v.55, p.71-79, 2019.

GONÇALVES, M.P.M et al. Variação radial da densidade básica e comprimento das fibras da madeira de Tectona grandis L. Radial variation of basic density and fi ber length of the wood of Tectona grandis L. Floresta e Ambiente, v.14, n.1, p.70-75, 2007.

GUIMARÃES, Í.L. et al. Caracterização química e física da madeira de procedências de Eucalyptus. Enciclopédia Biosfera, v.9, p.636645, 2013.

HURTADO, F.M.M. et al. Analysis of NAC domain transcription factor genes of Tectona grandis I.F. involved in secondary cell wall deposition. Genes, v.11, n.1, p.1-18, 2020.

IBÁ. Relatório 2019. 2019. Disponível em: https://iba.org/datafiles/publicacoes/relatorios/iba-relatorio anual2019.pdf

IWAKIRI, S. et al. Characteristics of glued laminated beams made of teak wood (Tectona grandis). Floresta e Ambiente, v.21, n.2, p.269-275, 2014.

KOLLERT, W.; KLEINE, M. The Global Teak Study IUFRO World Series Volume 36. Viena, 2017.

LEMOS, J.A.S. dos et al. Influência do método de propagação na produção e qualidade da madeira de Tectona grandis. Advances in Forestry Science, v.6, n.3, p.761-765, 2019.

LUKMANDARU, G.; TAKAHASHI, K. Variation in the natural termite resistance of teak (Tectona grandis Linn. fil.) wood as a function of tree age. Annals of Forest Science, v.65, n.7, p.708(1-8), 2008.

MIRANDA, I. et al. Wood properties of teak (Tectona grandis) from a mature unmanaged stand in East Timor. Journal of Wood Science, v.57, n.3, p.171-178, 2011.

MOTTA, J.P. et al. Natural resistance of Tectona grandis wood in laboratory assay. Ciencia Rural, v.43, n.8, p.1393-1398, 2013.

MOYA, R. et al. A review of heartwood properties of Tectona grandis trees from fast-growth plantations. Wood Science and Technology, v.48, n.2, p.411-433, 2014.

OLIVEIRA, G.F. de S. et al. Teor de taninos no lenho de Tectona grandis. Agropecuária Científica No Semiárido, v.15, n.3, p.144147, 2019b.

PALAKIT, K. et al. Influence of climate on the growth of teak (Tectona grandis Linn. F.) at a non-native distributed site in northeastern Thailand. Chiang Mai Journal of Science, v.46, n.6, p.1113-1128, 2019. 
PELISSARI, A.L. et al. Desenvolvimento quantitativo e qualitativo de Tectona grandis I.f. em mato grosso. Floresta e Ambiente, v.20, n.3, p.371-383, 2013.

PÉREZ, J. et al. Estimación del carbono almacenado en una plantación de Tectona grandis L. f. mediante ecuaciones alométricas. Revista Mexicana de Ciencias Forestales, v.11, n.57, p.32-56, 2020.

POLTRONIERI, L.S. et al. Tectona grandis, nova hospedeira de Rhizoctonia solani no Pará. Summa Phytopatholy, v.34, p.291, 2008.

PRIYA, P.B.; BHAT, K.M. Influence of rainfall, irrigation and age on the growth periodicity and wood structure in teak (Tectona grandis). IAWA Journal, v.20, n.2, p.181-192, 1999.

QIU, H. et al. Analysis of chemical composition of extractives by acetone and the chromatic aberration of teak (Tectona grandis L.F.) from China. Molecules, v.24, n.10, p.1-10, 2019.

QUEIROZ, F.L.C. et al. Intemperismo artificial em lâminas de Tectona grandis tratadas com produtos de acabamento. Floresta e Ambiente, v.23, n.4, p.573-581, 2016.

RENCHER, A.C. Methods of multivariate analysis. 2.ed. A John Wiley \& Sons, INC. publication, 2002.

RICA, C. et al. Chemical composition of the wood essential oil of Tectona grandis. American Journal of Essential Oils and Natural Products, v.7, n.4, p.23-24, 2019.

ROCHA, H.F. da et al. Plantios comerciais de Tectona grandis L.f. no Brasil. Multitemas, v.20, n.48, p.9-28, 2015.

RONDON, E.V. Estudo de biomassa de Tectona grandis L.f. sob diferentes espaçamentos no estado de Mato Grosso. Revista Árvore, v.30, p.337-341, 2006.

ROSAMAH, E. et al. Chemical content in two teak woods (Tectona grandis Linn.F.) that has been used for 2 years and 60 years. 3BIO: Journal of Biological Science, Technology and Management, v.2, n.1, p.15-19, 2020.

SANQUETTA, M.N. et al. Contribuição de um segundo diâmetro na estimação de volume individual de plantios jovens de Tectona grandis L.f. Revista Agro@Mbiente on-Line, v.9, n.4, p. 446-454, 2016.

SANTOS, M.L. dos et al. Hypsometric models for a clonal plantation of Tectona grandis Linn F. subjected to selective thinning. Revista Agro@mbiente on-Line, v.13, p.35-45, 2019.

SILVA, K.L. et al. Occurrence of Tectona grandis stem injury caused by cornitermes cumulans termite. Floresta e Ambiente, v.26, n.3, p.1-5, 2019.

SOUZA, D.V. et al. k-Nearest Neighbor Regression in the Estimation of Tectona Grandis Trunk Volume in the State of Pará, Brazil. Journal of Sustainable Forestry, v.38, n.8, p.755-768, 2019a.

SOUZA, R.S. et al. Anatomical characteristics of Tectona grandis L.f. from different sites in Mato Grosso state. Ciencia Florestal, v.29, n.4, p.1528-1537, $2019 b$.

SURYANTI, V. et al. Identification of active compounds and antioxidant activity of teak (Tectona grandis) leaves. Biodiversitas, v.21, n.3, p.946-952, 2020.

SCHUHLI, G.S; PALUDZYSZYN FILHO, E. O cenário da silvicultura de Teca e perspectiva para o melhoramento genético. Pesquisa Florestal Brasileira, v.30, p.217-230, 2010.

TSUKAMOTO FILHO, A.A. de. et al. Análise econômica de um plantio de teca submetido a desbastes. Revista Árvore, v.27, n.4, p.487-494, 2003.

VAIDES-LÓPEZ, E. et al. Site characteristics that determine the growth and productivity of teak (Tectona grandis I. F.) of young plantations in Guatemala. Agronomía Costarricense, v.43, n.1, p.135-148, 2019.

Recebido em 28-04-2021

Aceito em 08-07-2021 